\title{
Effect of Sudden and Gradual Transfer of Oreochromis aureus to Different Water Salinities on the Activity of AST and ALT Serum Enzymes
}

\author{
Layla M. A.A. AlKatrani, Faleh M. Jaafer and *Mohammed A. Aldoghachi \\ Vertebrate Dep., Marine Science Center, Basrah Univ., Iraq \\ *m_dogachi71@yahoo.com
}

\begin{abstract}
The effects of Sudden and Gradual salinities stress on AST and ALT enzyme activity in Oreochromis aureus fingerlings were investigated in two separate experiments in this study. The fingerlings were suddenly transferred to five different set of salinities $(5,15,25,35,45 \mathrm{psu})$ and gradually each one hour to seven set of salinities $(5,10,15,20,25,30,35)$ psu in two replicate for each salinity for $72 \mathrm{hrs}$. Fish were killed after that and blood were taken from heart and putted in test tubes for serum separation and serum kept in freeze until doing measurements of AST and ALT enzymes. Results showed that all fishes were died in the salinity concentration 45 psu after 20 hrs of sudden transfer, while a $100 \%$ survival rate was recorded in other salinity concentrations. The salinity 45 psu was considered to be out of the $O$. aureus tolerance range. Findings showed a close correlation of AST and ALT concentrations with salinity increase in sudden and gradual transfer experiments as a result of the stress which occurred during fish acclimation to reach the homeostasis. The remarkable increase in serum ALT and AST of fish groups exposed to sudden transfer compared with gradual transfer groups reflect the better ability of these fishes to adapt in salinity changes of gradual transfer..
\end{abstract}

Keywords: Salinities, Enzymes, Serum, Oreochromis aureus, Sudden transfer, Gradual transfer.

\section{Introduction}

Freshwater fishes have been divided into six main groups in different abilities to penetrate marine waters and according to their ability to penetrate marine waters all families of freshwater fishes have been placed in one of the following divisions divided into six categories (Banarescu, 1990; 1992) to: Primary, Secondary, Diadromous, Vicarious, Complementary and Sporadic.

However, most species in the secondary category (which include fish of our study) have a tolerance to salinity that greatly exceeds that of seawater and thus are potentially able to penetrate and disperse throughout the sea, even though they have not used this ability, they and usually have narrow ranges of salinity tolerance. Therefore, salinity tolerance alone cannot be used to define this fish category.

Changes in environmental salinity as a stressor can cause a physiological and morphological changes in osmoregulatory system of fish (Sangiao-Alvarellos et al, 2005; Arjona et al., 2007; Iwama et al., 2006). This osmoregulation is an energy demanding process that requires mobilization of energy substrates from the body (Vargas-Chacoff et al., 2009; Shahkar et al., 2015) which ordered through using hormones and enzymes as a systematic physiological response by fish against stressor to return to homeostasis (Eddy, 2006). 
The aminotransferases ALT (alanine aminotransferase) and AST (Aspartate aminotransferase) are intracellular enzymes released by cell damage or death, they are used as specific indicators of hepatotoxicity and histopathological changes and have been considered as indicators of hepatic dysfunction and damage (Sopinka et al., 2016; Datta et al., 2007). They are dominant in cardiomyocytes and hepatocytes, respectively (Bhattacharya et al., 2008). Literature reported that tissue damages of liver, kidney and gills of fish were correlated with high levels of AST and ALT activities (Oluah, 1999; Sopinka et al., 2016). When liver and myocardiocytes are damaged or their permeability increased, ALT and AST are released into the blood (Wang et al., 2005; Gholami-Seyedkolaei et al., 2013; Sopinka et al., 2016).

The increment of Alanine transaminase (ALT) and Aspartate transaminase (AST) levels occurs during nervous shock, hypoxia and stress where their plasma standard levels would be affected by several factors such as pollution, ammonia and nitrite toxicities and salinity (Das et al., 2004). When the fish suffer from a liver tissue destruction, ALT and AST concentration would increase because of their role in an initial amino acids compensation and formation that the body needs in physiological changes by increasing the energy demand or malnutrition (Ebeid et al., 2005).

The aim of this study was to investigate the stress effect of sudden and gradual salinity increasing on the activity and concentration of serum ALT and AST levels in fingerlings of Oreochromis aureus.

\section{Materials and Methods}

\subsection{Experimental Fishes}

A total of 120 fingerlings of Oreochromis aureus were collected from local fish farm in marine science center, university of Basrah which has a temperature and salinity mean of $(15.22 \pm 0.12){ }^{\circ} \mathrm{c}$ and $(3.46 \pm 0.20)$ psu respectively, and these fingerlings are divided into two groups; 50 individual of the first group were transferred suddenly to five different set of salinities $(5,15,25,35,45)$ psu, 5 individuals placed for each aquarium (in duplicate). Whereas 70 individual of the second group were transferred gradually each one hour to seven set of salinities $(5,10,15$, $20,25,30,35) \mathrm{psu}$ in 2 replicate for each salinity by using 24 glass aquaria $(30 \times 30 \times$ $60) \mathrm{cm}$ in a capacity of 50 L. 5 individuals putted per aquarium were used for each trial (per aquarium), each aquarium was filled with tap water free from chlorine. It, provided with aerators and covered by nets to prevent fish from jumping. The salinities of containers were corrected according to the designed experiment using marine salt which sailed from Faw city south of Basrah/ Iraq.

\subsection{Fish Sampling and Blood Collection}

After 72 hrs from sudden and gradual transfer to the different salinities, fishes were killed from each test aquarium after being anesthetized by clove oil by put it in a container with water have the same salinity they taken from and adding clove oil to the water (Durvill\& Collet, 2001). There total length $(11.59 \pm 0.11 \mathrm{~cm})$ and total weight $(34.57 \pm 0.60 \mathrm{~g})$ were recorded. Blood samples were collected from the heart by a $3 \mathrm{ml}$ syringe to sterile tubes and the serum was separated by centrifugation and kept in freeze at $-20 \mathrm{c}^{\mathrm{o}}$.

\subsection{AST and ALT Activity Determination}

The AST and ALT activities in the serum of $O$. aureus were determined by using a commercially available kits supplied by Syrbio (Syrian company). All reagents that provided by manufacturer were ready for use which are: [GOT Substrate (R1): (phosphate buffer $\mathrm{pH}$ 7.4), Aspartate, Oxoglutarate; GOT color reagent (R2): DNPH; $\mathrm{NaOH} 0.4 \mathrm{~N}$ ] for 
AST and [GPT Substrate (R1): (phosphate buffer $\mathrm{pH}$ 7.4), alanine, Oxoglutarate; GPT color reagent (R2): $\mathrm{DNPH} ; \mathrm{NaOH} 0.4 \mathrm{~N}]$ for ALT. and stored at $2-8{ }^{\circ} \mathrm{C}$.

\section{Assay Procedure}

All the specimens and working reagents were transported to room temperature (18-25 ${ }^{\circ} \mathrm{C}$ ) before use and the temperature was kept constant for the test duration $\left( \pm 0.5^{\circ} \mathrm{C}\right)$.

After mixing (100) $\mu \mathrm{l}$ of the sample with (500) $\mu \mathrm{l}$ of the substrate R1, the mixture was incubated for 30 minutes at $37^{\circ} \mathrm{c}$, then $500 \mu \mathrm{l}$ of the color reagent (R2) was added and incubated for 20 minutes at $25^{\circ} \mathrm{c}$. Finally $5 \mathrm{ml}$ of $\mathrm{NaOH} 0.4 \mathrm{~N}$ was added and the absorbance was read at $546 \mathrm{~nm}$ using a spectrophotometer model (Humalyzer Primus). The AST and ALT activities were calculated in the U/L unit.

\section{Statistical Analysis}

One - way analysis of variance (ANOVA) and Revised Least Significant Difference (RLSD) were used to compare the variances between treatments in sudden and gradual transfer experiments. $(\mathrm{P}<0.05)$ was set as the significance level using SPSS program (version 20). Values were expressed as the mean $( \pm$ S.D.; the standard deviation of the mean) (Steel et al., 2006).

\section{Results}

Table 1 shows the AST and ALT activity (U/l) for the $O$. aureus serum in the sudden transfer experiment to different salinities $(5,15$, 25, 35 and $45 \mathrm{psu}$ ) for $72 \mathrm{hrs}$. The AST activity of these salinities was found to be directly correlated with salinity increase. The control salinity 5 psu gave results in the lowest values of the AST activity $(30.19 \pm 0.15 \mathrm{U} / \mathrm{l})$. The salinity 35 psu gave the highest values of the AST activity (121.43 $\pm 1.02 \mathrm{U} / \mathrm{l})$. Also ALT activity showed a direct correlation with salinity increase in spite of its low values compared to AST values. The control salinity 5 psu resulted in the lowest values of the ALT activity $(11.6 \pm 0.56)$ U/l while the salinity 35 psu produced the highest ALT activity (30.00 $\pm 0.50 \mathrm{U} / \mathrm{l})$ (Fig. 1). All fishes transferred suddenly to the salinity 45 psu were died after $20 \mathrm{hrs}$ of transfer so the salinity 45 psu was considered to be out of the $O$. aureus tolerance range.

Experimental findings showed there were a significant differences $(\mathrm{P}<0.05)$ of the AST and ALT concentrations among all salinities at the end time of the sudden transfer experiment.

Table 2 shows the AST and ALT activity (U/l) for the $O$. aureus serum in the gradual transfer experiment to different salinities (5, $10,15,20,25,30$ and $35 \mathrm{psu}$ ) for $72 \mathrm{hrs}$. The AST and ALT activity correlated directly with salinity increase of the gradual transfer experiment. The control salinity 5 psu gave the lowest values of the AST activity (6.64 \pm 0.18$)$ U/1. The salinity $35 \mathrm{psu}$ gave the highest values of the AST activity (72.89 \pm 0.77$) \mathrm{U} / \mathrm{l}$. Also the control salinity 5 psu gave the lowest values of the ALT activity (4.94 \pm 0.07$) \mathrm{U} / \mathrm{l}$ while the highest values of the ALT activity $(24.09 \pm 0.03) \mathrm{U} / \mathrm{l}$ was recorded in the highest salinity 35 psu (Fig. 1).

Table 1. AST and ALT activity (U/l) for the O. aureus serum in the sudden transfer experiment to different salinities. (Mean \pm S.E).

\begin{tabular}{|c|c|c|}
\hline Salinity & AST & ALT \\
\hline $5 \mathrm{psu}$ & $\begin{array}{c}30.19 \pm 1.5 \\
\mathrm{D}\end{array}$ & $\begin{array}{c}11.6 \pm 0.56 \\
\mathrm{~d}\end{array}$ \\
\hline $15 \mathrm{psu}$ & $\begin{array}{c}47.6 \pm 1.36 \\
\mathrm{C}\end{array}$ & $\begin{array}{c}19.18 \pm 0.64 \\
c\end{array}$ \\
\hline $25 \mathrm{psu}$ & $\begin{array}{c}96.85 \pm 1.57 \\
\text { B }\end{array}$ & $\begin{array}{c}24.00 \pm 0.50 \\
b\end{array}$ \\
\hline $35 \mathrm{psu}$ & $\begin{array}{c}121.43 \pm 1.02 \\
\mathrm{~A}\end{array}$ & $\begin{array}{c}30.00 \pm 0.50 \\
\mathrm{a}\end{array}$ \\
\hline $45 \mathrm{psu}$ & $\begin{array}{c}\text { all fish died after } 20 \mathrm{hrs} \\
\text { of transfer }\end{array}$ & $\begin{array}{c}\text { all fish died after } 20 \\
\text { hrs of transfer }\end{array}$ \\
\hline
\end{tabular}

*The capital letters $(\mathrm{A}, \mathrm{B}, \mathrm{C})$ means a significant differences in AST activity among the groups of Oaureus in the sudden transfer experiment to different salinities.

**The small letters $(\mathrm{a}, \mathrm{b}, \mathrm{c})$ means a significant differences in ALT activity among the groups of O.aureus in the sudden transfer experiment to different salinities. 
Statistical analysis showed that there are no significant differences $(\mathrm{P}>0.05)$ between the salinities $(5,10)$ psu and $(30,35)$ psu for the ALT activity at the end time of the gradual transfer experiment. And there were significant differences $(\mathrm{P}<0.05)$ of the AST concentrations among all salinities at the end time of the sudden transfer experiment.

In a comparison between sudden and gradual transfer effects on AST and ALT activities in $O$. aureus serum a clear depression of these enzymes activities in the gradual transfer experiment at the same salinities (Fig. 1) was observed. Statistical analysis showed a significant difference $(\mathrm{P}<$ $0.05)$ between the same salinities of ALT and AST activities in the sudden and gradual transfer experiments.

Table 2. AST and ALT activity (U/l) for the O. aureus serum in the gradual transfer experiment to different salinities. (Mean \pm S.E).

\begin{tabular}{|c|c|c|}
\hline Salinity & AST & ALT \\
\hline $5 \mathrm{psu}$ & $6.64 \pm 0.18$ & $4.94 \pm 0.07$ \\
& $\mathrm{G}$ & $\mathrm{e}$ \\
\hline $10 \mathrm{psu}$ & $12.39 \pm 0.23$ & $6.88 \pm 0.00$ \\
& $\mathrm{~F}$ & $\mathrm{e}$ \\
\hline $15 \mathrm{psu}$ & $20.76 \pm 0.65$ & $9.12 \pm 0.48$ \\
& $\mathrm{E}$ & $\mathrm{d}$ \\
\hline $20 \mathrm{psu}$ & $29.27 \pm 0.64$ & $12.96 \pm 0.96$ \\
& $\mathrm{D}$ & $\mathrm{c}$ \\
\hline $25 \mathrm{psu}$ & $34.01 \pm 0.55$ & $\begin{array}{c}19.17 \pm 1.66 \\
\mathrm{C}\end{array}$ \\
\hline $30 \mathrm{psu}$ & $55.23 \pm 1.02$ & $22.10 \pm 0.76$ \\
& $\mathrm{~B}$ & $\mathrm{a}$ \\
\hline $35 \mathrm{psu}$ & $72.89 \pm 0.77$ & $24.09 \pm 0.03$ \\
& $\mathrm{~A}$ & $\mathrm{a}$ \\
\hline
\end{tabular}

*The capital letters (A, B, C) means a significant differences in AST activity among the groups of O.aureus in the gradual transfer experiment to different salinities.

**The small letters $(a, b, c)$ means a significant differences in ALT activity among the groups of O.aureus in the gradual transfer experiment to different salinities.

\section{Discussion}

Our experimental findings indicated that the activity of AST and ALT in serum of $O$. aureus is directly increased with salinity increase in sudden and gradual transfer experiments to different salinities. Furthermore, there was a clear depression of these enzymes activities in the gradual transfer experiment at the same salinities than its activities in sudden transfer experiment. The highest values of the AST and ALT activities were $121.43 \mathrm{U} / \mathrm{l}$ and $30.00 \pm 0.50 \mathrm{U} / 1$, respectively, under the highest salinity 35 psu of the sudden transfer experiment, while. These enzymes activities were lowered to 72.89 ( \pm 0.77$) \mathrm{U} / \mathrm{l}$ and 24.09 ( \pm $0.03) \mathrm{U} / \mathrm{l}$ respectively at the same salinity in the gradual transfer experiment. This is agreeing with results of many literatures that reported the significant increment of AST and ALT activities with salinity increase. The study of Al-Kashali and Al-Shawi (2013) showed an intrinsic increment of AST and ALT activities in adults of gold fish Carassius carassius after gradual transfer from $0.1 \mathrm{~g} / \mathrm{L}$ to different salinities (4, 8 and $12 \mathrm{~g} / \mathrm{L})$. Also, Roche et al. (1989) recorded an increase in transaminases activities (AST and ALT) in seabass Dicentrarchus labrax acclimatized to salinity 5 $\mathrm{g} / \mathrm{L}$. Transferring Tilapias from freshwater to seawater for two weeks leads to a significant increase in AST and ALT activities in liver because of increase in liver protein destruction and energy demand (Vijayan et al., 1996). Salaei (2006) reported that plasma AST and ALT activity increased in Cyprinus carpio during catching process from ponds. Study of Sultan (2007) Reported an increase in plasma ALT and AST concentration with salinity increase in juveniles of Acanthopagrus latus which reared in $(3,23,30) \mathrm{g} / \mathrm{L}$ salt solution.

Study of Lee et al. (2016) suggested that Juveniles of Red-Spotted Grouper Epinephelus akaara exposed to sudden salinity drops from 34 psu to 18 or 10 psu still undergoes the primary adjustment phase ("alarming stage") before the fish reach a new homeostasis ("resistant stage").

This study showed that the serum AST and ALT concentrations are an obvious indicators of salinity exposure stress on 
fingerlings of Oreochromis aureus fish. However, AST activity was increased more than ALT. Brett (2009) explained that, the AST activity increased in the cytoplasm and then the ALT activity increased in the mitochondria and cytoplasm since fish are exposed to stress which lead to an increase in metabolic rate.

The gradual transfer of fingerlings of Oreochromis aureus fish to different salinities showed a better acclimation of fish than the sudden transfer which reflected in the depression of AST and ALT enzymes activities in gradual transfer experiment. These results are in agreement with study of Al-Faiz (2011) who found that the salt concentration
$13.1 \mathrm{~g} / \mathrm{L}$ was lethal to all fingerlings of silver carp Hypophthathmichthys molitrix after 48 hrs in gradual transfer, while the salt concentration $11.1 \mathrm{~g} / \mathrm{L}$ was lethal to all fishes after $24 \mathrm{hrs}$ in sudden transfer test, and then he concluded that the silver carp was able to tolerate a salinity concentration up to $11.1 \mathrm{~g} / \mathrm{L}$ in gradual transfer while this concentration was lethal in sudden transfer. Moreover, study of Soltanian and Fereidouni (2017) found that the extremely euryhaline mudskipper Periophthalmus waltoni can be acclimated to freshwater medium without showing any health disturbance when the experiment carried out in a gradual decrease in salinity for a long period of time.

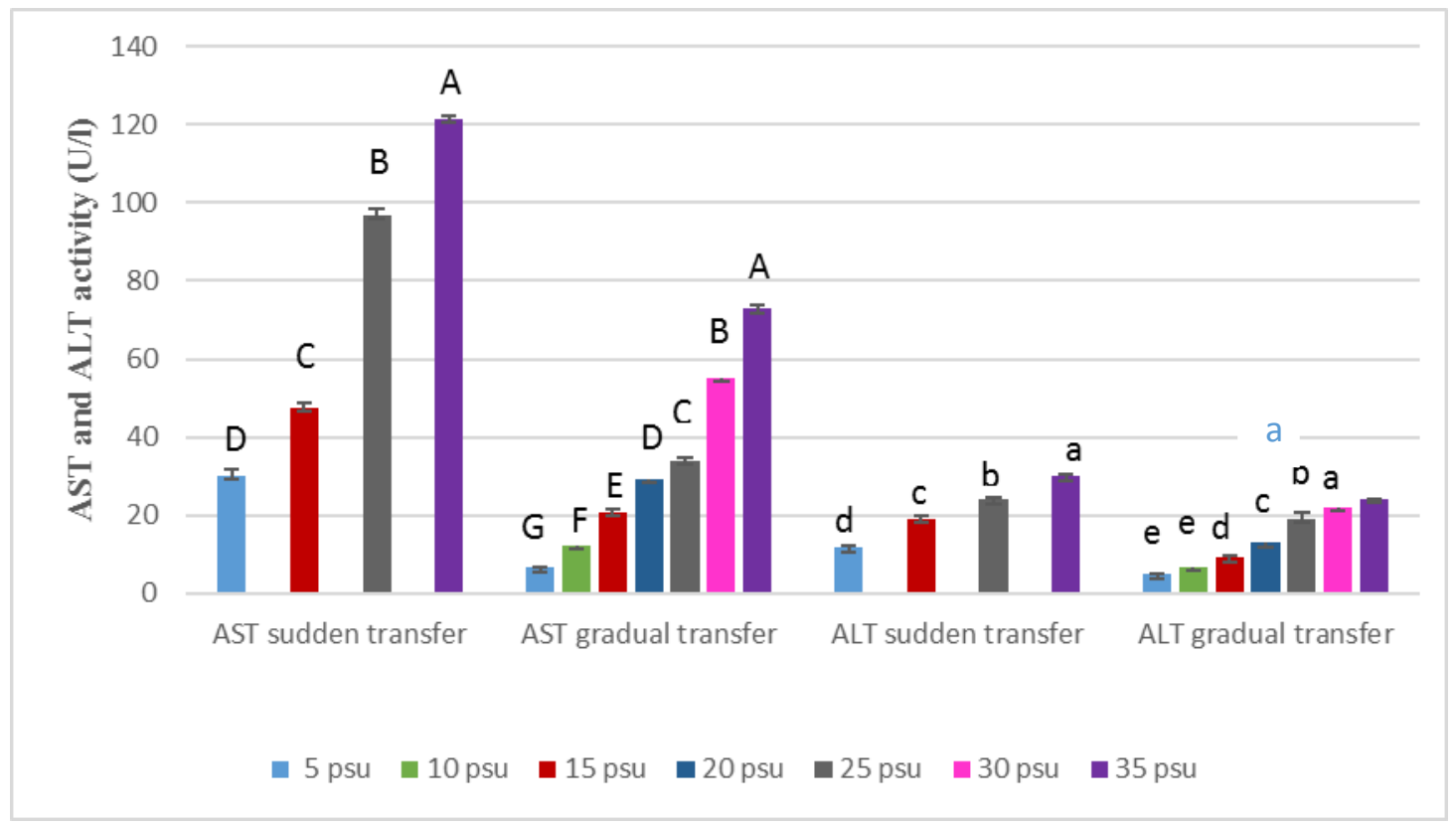

Fig. 1. ALT and AST activity (U/I) in serum of $O$. aureus in sudden and gradual transfer experiment to different salinities. The capital letters (A, B, C) means a significant differences in AST activities. The small letters (a, b, c) means a significant differences in ALT activities.

The impact of improving fish ability to live and tolerate high salinities in gradual transfer can be explained by the fish mortalities in sudden transfer to high salinities attributed to a sudden rise in the plasma ions concentration which can be a reason of fish failed to acclimate this abrupt change in salt stress (Bianco and Nordlie, 2008). Study of Alkatrani et al. (2014) on Tilapia zillii fingerlings showed that Sodium and chloride ions concentrations had a direct proportion with salinity increase in short term effect of 
different salinities experiment. Furthermore, Study of Eroldogan and Kumlu (2002) found a significant low in $\mathrm{Na}^{+}$and $\mathrm{Cl}^{-}$levels in blood of Dicentrarchus labrax fish grown for 90 days in freshwater than at seawater. They suggested that the stress and mortality occurring in fresh water transfer may be due to severe ion loss. However, after a gradual acclimation, no sign of stress in sea bass was evident as reflected in the growth data.

Our study was concluded that ALT and AST enzymes activities significantly depressed in the gradual transfer than at the sudden transfer and this reflect the better ability of $O$. aureus fingerlings to adapt the salinity changes in gradual transfer.

\section{References}

Al-Faiz, N.A. (2011). Salinity tolerance of silver carp Hypophthalmichthys molitrix fingerlings transferred suddenly and gradually to a different saline. The 4th international scientific conference of Salahaddin University-Erbil, October 18-20, 2011; pp: 524-527.

AlKashali, M. Sh. and Al-Shawi, A. S. (2013). Effect of salt stress on ALT and AST enzymes activity and cortisol level in Adults of Carassius auratus. Pakistan Journal of Nutrition, 12(1): 97-100.

Alkatrani, L., Yesser, A. and Al-Adub, A. (2014). Estimating some physiological parameters in the blood of Tilapia zillii fingerlings during adaptation to different salinities. Mesopot. J. Mar. Sci., 29(2): 115 - 136.

Arjona, F.J., Vargas-Chacoff, L., Ruiz-Jarabo, I., Martin Del Rio, M.P. and Mancera, J.M. (2007). Osmoregulatory response of Senegalese sole (Solea senegalensis) to changes in environmental salinity. Comp. Biochem. Physiol., 148(A): 413-421.

Banarescu, P. (1990). Zoogeography of Freshwaters, Vol. I. General distribution and dispersal of freshwater animals. AULA-Verlag publisher, Wiesbaden, Germany. ISBN 3-89104-480-1, $511 \mathrm{pp}$.

Banarescu, P. (1992). Zoogeography of Freshwaters, Vol. II. Distribution and dispersal of freshwater animals in North America and Eurasia. AULA-Verlag publisher, Wiesbaden, Germany ISBN n 3-89104-482-8, 519$1091 \mathrm{pp}$.

Bhattacharya, H., Xiao, Q. and Lun, L. (2008). Toxicity study of nonylphenol on rosy barb (Puntius conchonious): A biochemical and histopathological evaluation. Tissue Cell; 40:243-249.
Bianco, P.G. and Nordlie, F. (2008). The salinity tolerance of Pseudophoxinus stymphalicus (Cyprinidae) and Valencia letourneuxi (Valenciidae) from western Greece suggests a revision of the ecological categories of freshwater fishes. Italian Journal of Zoology, September 2008; 75(3): 285293

Brett, D. Glencross (2009). Exploring the nutritional demand for essential fatty acids by aquaculture species. Reviews in Aquacultur, 1: 71-124.

Das, P. C.; Ayyappan, S.; Jena, J. K. and Das, B. K. (2004). Acute toxicity of ammonia and its sub-lethal effects on selected haematological and enzymatic parameters of mrigal Cirrhinus mrigala (Hamilton). Aquacult. Res., 35: 134-143.

Datta, S., Saha, D.R., Ghosh, D.; Majumdar, T., Bhattacharya, S. and Mazumder, S. (2007) Sub-lethal concentration of arsenic interferes with the proliferation of hepatocytes and induces in vivo apoptosis in Clarias batrachus L. Comp. Biochem. Physiol. Part C. Toxicol. and Pharmacol.; 145 (3): 339-349.

Durville, P. and Collet, A. (2001). Clove oil used as an anesthetic with juvenile tropical marine fish. SPC Live Reef Fish Information Bulletin, 9 (December 2001): 1719.

Ebeid, T. A., Eid, Y. Z. and El-Habbak, M. M. (2005). Liver and Kidney function parameters in Avian species. Review, proceeding of the 3rd International Poultry Conference, 47 April, Hughada, Egypt.

Eddy, F. B. (2006). Cardiac function in juvenile salmon (Salmo salar L.) in response to lipopolysaccharide (LPS) and inhibitor of inducible Nitric Oxide Synthase (iNOS). Fish. Physiol. Biochem., 31(4): 339-346.

Eroldogan, O T. and Kumlu, M. (2002). Growth performance, body traits and fillet composition of the european Sea Bass (Dicentrarchus labrax) reared in various salinities and fresh water. Turk J Vet Anim. Sci., 26: 993-1001.

Gholami-Seyedkolaei, S.J., Mirvaghefi, A., Farahmand, H., Kosari, A.A.; Gholami-Seyedkolaei, S.J. and Gholami-Seyedolaei, S.J. (2013). Optimization of recovery patterns in common carp exposed to roundup using response surface methodology: Evaluation of neurotoxicity and genotoxicity effects and biochemical parameters. Ecotox. Environ. Saf.; 98: 152-161.

Iwama, G.K., Afonso, L.O.B. and Vijayan, M.M. (2006). Stress in fishes. In: The Physiology of Fishes (eds. Evans, D.H. and Claiborne, J.B.), 319-342. Taylor and Francis, 3rd Ed., USA. Pages: 601.

Lee, J.W., Kim, H.B. and Baek, H.J. (2016). Plasma Stress Responses in Juvenile Red-Spotted Grouper (Epinephelus akaara) exposed to Abrupt Salinity Decrease. Dev. Reprod., 20 (3): 187-196. 
Oluah, N. S. (1999). Plasma aspartate aminotransferase activity in the catfish Clarias albopunctatus exposed to sublethal zinc and mercury. Bulletin of Environmental Contamination and Toxicology; 63(3): 343-349.

Roche, H., Chaar, K. and Peres, G. (1989). The effects of a gradual decrease in salinity on the significant constituents of tissue in the sea bass (Dicentrarchus labrax Pisces) Comp. Biochem. Physiol.; 93(4): 785-789.

Salaei, V.S.M. (2006). The effect of substitution of soybean meal by cotton seed cake in common carp Cyprinus carpio diet. Degree of Master. University of Salahaddin - Arbil, 63 pp.

Sangiao-Alvarellos, S., Arjona, F.J., Martin del Rio, M.P. Miguez, J.M., Mancera, J.M. and Soengas, J.L. (2005). Time course of osmoregulatory and metabolic changes during osmotic acclimation in Sparus auratus. J. Exp. Biol.; 208: 4291-4304.

Shahkar, E., Kim, D-J., Mohseni, M., Yun, H. and Bai, S.C. (2015). Effects of salinity changes on hematological responses in juvenile ship sturgeon Acipenser nudiventris. Fish Aquat. Sci.; 18:45-50.

Soltanian, S. and Fereidouni, M. S. (2017). Haematological, blood biochemical and immunological responses to gradual acclimation to low-salinity water in Walton's mudskipper Periophthalmus waltoni Koumans, 1941 (Perciformes: Gobidae). Bulgarian Journal of Veterinary Medicine (BJVM), $\mathbf{X X}(\mathrm{X}): 1-13$.
Sopinka, N.M., Donaldson, M.R., O'connor, C.M., Susuki, C.D. and Cooke, S.J. (2016). Stress indicators in fish. Fish Physiology, 35:405-462.

Steel, R. G. D., Torrie, J. H. and Dikey, D.A. (2006). Principles and Procedures of Statistics. A Biometrical Approach. $3 r d$ Ed. CRAM101 publisher, Sim Valley, CA, USA. 156 pp.

Sultan, F.A.M. (2007). Effect salinity acclimation on some physiological and nutritional aspects in Acanthopagrus latus (Houttyn, 1782) Juveniles. Ph.D. Thesis, Agriculture College, Basrah Univ., 162 p.

Vargas-Chacoff, L., Arjona, F. J., Polakof, S., Martin del Rio, M.P., Soengas, J.L. and Mancera, J.M. (2009). Interactive effects of environmental salinity and temperature on metabolic responses of gilthead sea bream Sparus aurata. Comp. Biochem. Physiol. Part A: Molecular and integrative physiology; 154 (3): 417-424.

Vijayan, M. M., Morgan, J.D., Sakamoto, T., Gran, E.G. and Iwama, G.K. (1996). Food deprivation effects seawater acclimation in tilapia: Hormonal and metabolic changes. J. Exp. Biol., 199: 2467-2475.

Wang, Y., Xiong, L., Yang, K., Wu, Z., Sheng, X., Tang, H. and Lui, X. (2005). Effect of beta-cypermethrin on GPT and GOT activities of crucian serum. Agr. Sci. Technol.; 6 (1): 20-23. 
تأثنير النقل المباشر والتدريجي للملوحات المختلفة على نشاط إنزيمي AST و ALT في Oreochromis aureus مصل أسماك التيلابيا

ليلى مصطفى عبدالكريم القطراني، و فالح موسى جعفر، و محمد عبدالرضا الدوغجي*

$$
\text { قسم الفقريات البحرية، مركز علوم البحار، جامعة البصرة، العراق }
$$

الدستخلص. درس نأثير الإجهاد الناجم عن النقل المباشر والتنريجي إلى ملوحات مختلفة على الثى

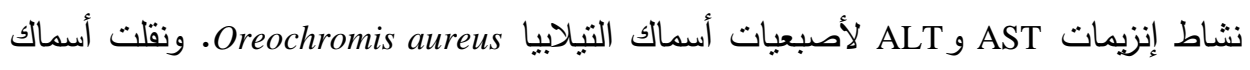

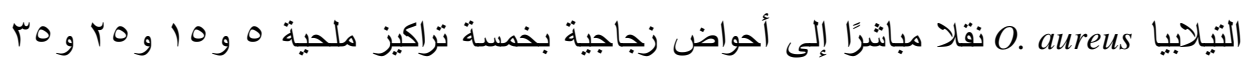

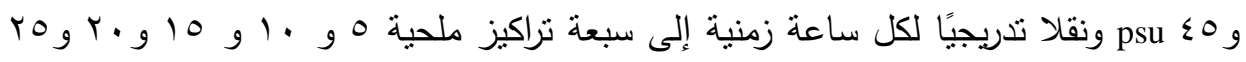

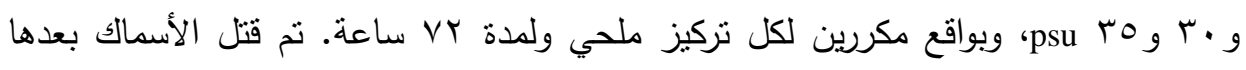

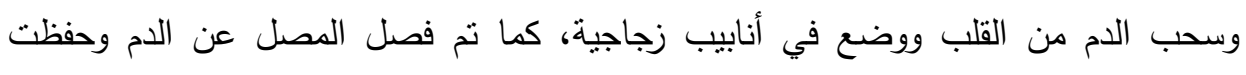

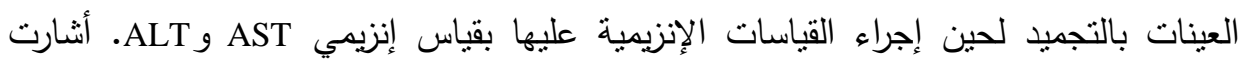

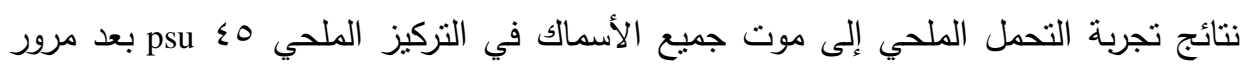

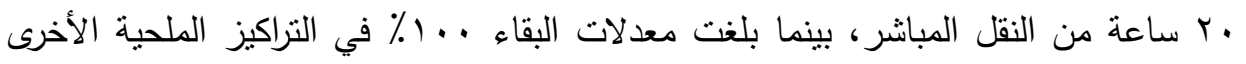

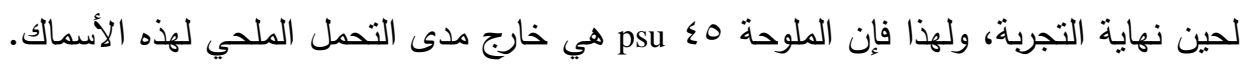

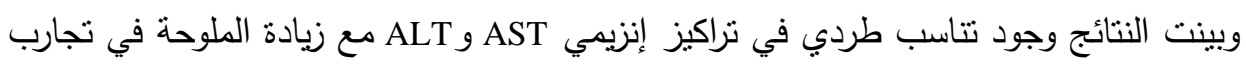

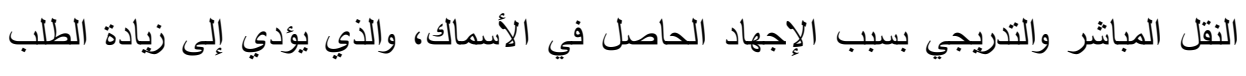

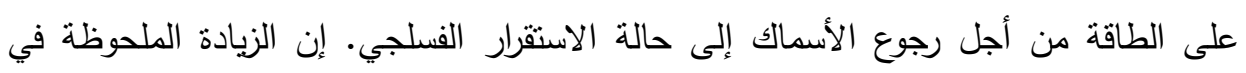

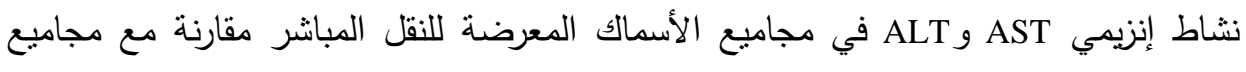
النقل التنريجي تعكس القدرة الأفضل لهذه الأسماك لكي تتكيف مع التغيرات الملحية الحاصلة عند النقل التدريجي.

كلمات مفتاحية: الملوحة، الإنزيمات، المصل، أسماك النيلابيا Oreochromis aureus، النقل

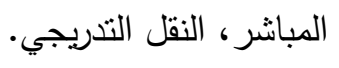

